\title{
The Relationship Between Nursing Students' Education Stress Level and Their Perception Level Professional Values
}

\section{Hemşirelik Öğrencilerinin Eğitim Stres Düzeyi ile Mesleki Değerleri Algılama Düzeyi Arasındaki İlişki}

\begin{abstract}
Aim: The purpose of this study was to determine the relationship between nursing education stress levels and senior year nursing students' perception level of professional values. Introduction: In addition to the difficulties of university education, nursing students experience intense stress during theoretical and clinical practice due to encounters related to patients, patient relatives, educators, and the hospital environment. In addition, stress may negatively affect academic functioning, reduce educational efficiency, and negatively impact learning, performance, and professional identity acquisition.

Method: This research is relational and descriptive. A total of 300 a nursing faculty senior year students were recruited for the study. A sampling method was not used in the study; instead, it aimed to reach participants worldwide. The research was completed with 255 students who agreed to participate in the research. The research data were collected using the Personal Information Form, Nursing Education Stress Scale, and the Nurses' Professional Values Scale. Results: The study found that nursing students in their senior year had high stress levels, and their perception of professional values were positive. It was determined that there was a significant positive correlation between the total and sub-dimensions mean scores of the Nursing Education Stress Scale, the Nurses' Professional Values Scale total, and factors' mean scores $(p<0.05)$. It was observed that, as stress increased, their perception of professional values also increased.

Conclusions: In line with the results of this research, it is recommended to determine the factors that cause stress in the academic and clinical application areas of the students and to reorganise nursing education programs to create programs to help nursing students cope with these stress factors.
\end{abstract}

Keywords: Nursing education stress, nursing students, professional values.
Recieved / Geliş: 25.02.2021

Accepted / Kabul: 25.08.2021

Published Online / Online Yayın: 25.12.2021

Corresponding author / Sorumlu yazar: Fatma Er

İnönü Üniversitesi, Malatya, Türkiye fatma.er@inonu@edu.tr ORCID: 0000-0001-8517-9780 


\section{Educational stress level of nursing students}

Hemşirelik öğrencilerinin eğitim stres düzeyi

\section{Öz}

Amaç: Bu araştırmanın amacı, hemşirelik öğrencilerinin hemşirelik eğitimi stres düzeyi ile mesleki değerleri algılama düzeyi arasındaki ilişkiyi belirlemektir.

Giriş: Hemşirelik öğrencileri, üniversite eğitiminin zorluklarına ek olarak, kuramsal ve klinik uygulama sırasında hastalar, hasta yakınları, eğitimciler ve hastane ortamıyla ilgili sorunlarla da karşılaştıkları için yoğun stres yaşamaktadırlar. Stres aynı zamanda akademik işlevleri olumsuz etkileyip, eğitim verimini düşürüp, öğrencilerin öğrenmelerine, performanslarına ve profesyonel kimlik kazanımına olumsuz etki edebilmektedir.

Yöntem: Bu araştırma, ilişkisel tanımlayıcı türde bir araştırmadır. Araştırmanın evrenini, bir hemşirelik fakültesi son sınıf öğrencileri (N:300) oluşturmaktadır. Araştırmada örneklem seçim yöntemine gidilmeyip, evrenin tamamına ulaşılmaya çalışılmış ve araştırmaya katılmayı kabul eden 255 öğrenci ile tamamlanmıştır. Araştırmanın verileri; "Kişisel Bilgi Formu, Hemşirelik Eğitimi Stres Ölçeği ve Hemşirelerin Mesleki Değerleri Ölçeği-Revize" kullanılarak toplanmıştır.

Bulgular: Bu araştırmada, hemşirelik öğrencilerinin son sınıfta yüksek stres düzeyine sahip oldukları ve mesleki değer algılarının olumlu olduğu belirlenmiştir. Hemşirelik eğitimi stres ölçeği toplam ve alt boyut puan ortalamaları ile hemşirelerin mesleki değerleri ölçeği toplam ve faktör puan ortalamaları arasında olumlu yönde önemli bir ilişki olduğu belirlenmiştir $(p<0.05)$. Öğrencilerin hemşirelik eğitimi stres düzeyi arttıkça mesleki değerleri algılama düzeyinin arttığı görülmektedir.

Sonuç: Bu araştırmanın sonuçları doğrultusunda öğrencilerin akademik ve klinik uygulama alanlarında strese neden olan etmenlerin belirlenmesi ve hemşirelik öğrencilerinin bu stres faktörleri ile baş etmelerine yardımcı olacak programların oluşturulması için hemşirelik eğitim programlarının yeniden düzenlenmesi önerilmektedir.

Anahtar Sözcükler: Hemşirelik eğitimi stresi, hemşirelik öğrencileri, mesleki değerler.

\section{Introduction}

Nursing education consists of theoretical knowledge and clinical practice that gives the student cognitive, sensory, and psychomotor nursing knowledge, skills, and attitudes (Karaca, Yıldıım, Ankaralı, Açıkgöz \& Akkuş, 2014; Kılıç, 2018). In addition to the difficulties of university education, nursing students experience intense stress during theoretical and clinical practice due to they also face problems related to patients, patient relatives, educators, and the hospital environment (Ağaçdiken, Boğa \& Özdelikara, 2016; Akkaya, Gümüş \& Akkuş, 2018; Karabulutlu, Oruç \& Turan, 2019; Kılıç, 2018; Singh, Sharma \& Sharma, 2011). At the same time, the economic status of nursing students, homework assignments, exams and advanced education (focusing on research-based knowledge) have been stated as common experienced academic stressors (Bloomberg, Bisholt, Engström, Johansson \& Gustafsson, 2014). Common clinical stressors including caring for fatal patients, communication problems with educators and staff in the clinical setting, lack of knowledge and skills, practical exams, and excessive workload have been reported in the researches. (Blomberg et al., 2014; Reeve, Shumaker, Yearwood, Crowell \& Riley, 2013). In particular, nursing students state that they have found few opportunities to practice and develop their professional skills in the clinical setting and it has been stated that clinical stress is common (Blomberg et al., 2014; Singh, Sharma \& Sharma, 2011). Therefore, many nursing students feel that clinical experience is one of the most anxious and stressful situations of nursing education (Ağaçdiken, Boğa \& Özdelikara, 2016). In a study conducted by Singh and friends in 2011, 63.6 percent of nursing students stated that they experienced stress due to the exams (Singh, Sharma \& Sharma, 2011). The high level of stress that nursing students experience during the education process may cause health problems such as physical, psychosocial, and behavioral disorders. In addition, stress may negatively affect academic function, reduce educational efficiency, and have a negative impact on learning, performance, and professional identity acquisition (Akkaya, Gümüş \& Akkuş, 2018; Karaca et al., 2011; Kılıç, 2018 Singh, Sharma \& Sharma, 2011). Specifically, nursing students gain professional nursing identity during school and also develop/learn professional values during this time (Acaroğlu, 2014). 


\section{Educational stress level of nursing students}

Hemşirelik öğrencilerinin eğitim stres düzeyi

Professional values are described as beliefs, guidelines, and generalized principles of ideal behaviors that provide a basic standard in judging actions and goals for individuals while performing their professional duties and responsibilities (Acaroğlu, 2014; Alkaya, Yaman \& Simones, 2018; Dündar, Özsoy, Toptaş \& Aksu, 2019). It is stated that the values represent basic states of what is right, good, or desired and they motivate social and professional behaviors (Alkaya et al., 2018; Avcı, Işık, Cetişli, Üşümez, Şencandan \& Bektaş, 2019). It is stated that professional values form the basis of professional nursing practices (Bleda, Alvarez \& Prat (2020). Values in nursing form the basis of practice and determine what is right and important for nurses (Arries, 2020; Elmalı, 2020). Gaining professional values in nursing is critical for professional development (Bang et al., 2011). For example, nurses should act with professionalism while caring for healthy/ sick individuals, advocating for their behavior and attitudes, and deciding when they encounter any ethical dilemma (Acaroğlu, 2014; Can \& Acaroğlu, 2015; Karadağlı, 2016; Lacobucci, Daly, Lindell \& Griffin, 2012). The internalization of professional values contributes to solving problems, maintaining a safe, qualified, and ethical patient care and also a professional responsibility of the individual (Acaroğlu, 2014; Arkan, Ordin \& Haney, 2019). Learning professional values starts in nursing school and the development of these values continues after graduation (Acaroğlu, 2014; Arkan, Ordin \& Haney, 2019). Earning these values early enables nurses to be more successful in their interpersonal relationships and can help with communication skills for professional life, team work, nursing care practices and ethical decision making (Dündar et al., 2019).

Since the development of professional values of nursing students began, educational stress may affect their perception of professional values. There have been other studies in Turkey that determine the level of nursing education stress and perception of professional values. However, there has been no study evaluating both the level of nursing education stress and the perception of professional values together. Therefore, this study was planned to determine the relationship between the stress level of nursing education and the perception of professional values; and to determine the factors that cause the senior nursing students to experience the most stress in theoretical and practical lessons during their four-year education and take necessary precautions for these factors.

\section{Method}

Aim and Type of the Research: The aim of this study was to determine the relationship between the nursing education stress level and senior nursing students' perception of professional values. This research is relational and descriptive.

Research Questions: Based on this research, answers to the following questions were sought:

- What is the educational stress level of senior nursing students?

- Is there any difference among the senior nursing students' educational stress level according to the identified characteristics?

- What is the level of senior nursing students' perception of professional values?

- Is there a difference among the senior nursing students' level of perception of professional values according to the identifying characteristics determined?

- Is there a relationship between the senior nursing students' educational stress level and their perception of professional values?

Place and Time of the Study: The research was carried out between February 15 and 2020 March 15, 2020 at X Nursing Faculty.

Research Universe and Sample Selection: A total of 300 a nursing faculty senior year students were recruited for the study. In the research, the method of sampling was not used, but the whole universe was tried to be reached. When the data were collected, students who were absent, had health problems, or did not want to participate in the study were not included $(n=255)$. The reason why the universe of the study is only for senior nursing students is that students' perception and assimilation of professional values are more common in the last years of the university. Because students do not yet know the profession in the first years of school and they can understand professional values over the years. 


\section{Educational stress level of nursing students}

Hemşirelik öğrencilerinin eğitim stres düzeyi

Data Collection Tools: The data of the study were collected using the Personal Information Form prepared by the researcher, Nursing Education Stress Scale and Nurses' Professional Values Scale.

Personal Information Form: It includes the introductory characteristics of the students participating in the study consisting of 10 questions.

Nursing Education Stress Scale: The scale was developed by Rhead in 1995 by modifying the Nurse Stress Scale developed by Gray-Toft and Anderson in 1981 (Gray-toft \&Anderson, 1981; Rhead, 1995). The validity and reliability of the scale for our country was tested in 2014 in a group of nursing undergraduate students by Karaca et al. (Karaca et al., 2014). The scale is a Likert type scale with a score of $0-3$. " 3 " indicates very stressful situation and "0" indicates no stressful situation (Karaca et al., 2014). The scale consists of 32 items, 2 sub-dimensions including academic and clinical stress. Clinical stress consists of items numbered 4, 5, 7, 9, 11, 13, 15, 16, 18, 19, 21, 24, 25, 27, 29, and 32. Academic stress consists of items numbered $1,2,3,6,8,10,12,14,17,20,22,23,26,28,30$, and 31 . Each sub-dimension takes values between $0-48$. The total score of the scale is between $0-96$, and the increase in the score indicates that stress increases (Karaca et al., 2014). Cronbach Alpha reliability coefficient of clinical stress sub-dimension of the scale, academic stress sub-dimension, and total Cronbach Alpha reliability coefficient was 0.84, 0.83, and 0.90, respectively (Karaca et al., 2014). In this study, Cronbach Alpha reliability coefficient of the scale was found to be 0.92 .

Nurses' Professional Values Scale: The scale was developed by Weis and Schank in 2000 to determine the level of perception of the professional values of nurses and nursing students, reflecting the Nursing Ethics Codes of the American Nurses Association (ANA) (Schank \& Weis, 2000). The first 44-item version of the scale was adapted to Turkish society by Orak and Alpar as the "Professional Values Scale of Nurses" in 2012 (Orak \& Alpar, 2012). The scale was revised in 2009 by Weis and Schank and a 26-item version was created. The scale is a 5-point Likert type scale (1-not important, 2-somewhat important, 3-important, 4-very important, 5-very much important). The total scores that can be obtained from the scale are between 26-130 (Weis \& Schank, 2009). High score that are in compliance with professional values were considered strong. The scale was supported by five factors: Care, Activism, Confidence, Professionalism and Justice. There are no inverted items in the scale (Weis and Schank, 2009). The Turkish Validity and Reliability of the Nurses' Professional Values Scale-Revised version was conducted by Acaroğlu in 2014 (Acaroğlu, 2014). In Acaroğlu's adaptation study to Turkish, the Cronbach alpha reliability coefficient was determined to be 0.96 , and it was supported by three factors ranging from 0.49-0.82 (Acaroğlu, 2014). The factors were Care (number of items: 10, 12, 13, 14, 15, 16, 17, 18, 19, 20, 21, 22, 23, 24, and 25), Professionalism (number of items: 4, 5, 6, 7, 8, 9, 11, and 26) and Confidence (number of items: 1,2 , and 3 ). In this study, Cronbach alpha reliability coefficient of the scale was found 0.82 .

Collection of Data: The data of the research was collected by distributing and retrieving the questionnaire forms from the seniors who studied at a nursing faculty and who wanted to participate in the research voluntarily.

Evaluation of Research Data: The data obtained from the research were analyzed using the statistical package program SPSS 25.0 (Statistical Package for Social Sciences). In the evaluation of the data, number, percentage distribution, mean, standard deviation, t-test in parametric analysis in paired comparisons, and Mann Whitney U test in nonparametric analysis in paired comparisons were used. In multiple comparisons, One-Way Variance Analysis (ANOVA) test was used for parametric analysis and Kruskal Wallis $(\mathrm{KW})$ test and Pearson Correlation test were used for nonparametric analysis.

Ethical Principles of The Research: Written permission was obtained from a state university Health Sciences NonInterventional Clinical Research Ethics Committee for the research (Decision No: 2020/237). Necessary permissions were obtained from the scale owners via e-mail for the scale to be used in the study. In addition, written permission was obtained from a faculty of nursing and informed conselt was obtained from the students.

Limitations of the Research: This research is limited to senior undergraduate students studying at a nursing faculty in the east of Turkey. 


\section{Results}

The findings of this research conducted to determine the relationship between the nursing education stress level and the perception of professional values of senior nursing students were given below.

Table 1. The descriptive characteristics of the students participating in the research

\begin{tabular}{|c|c|c|}
\hline Descriptive characteristics (N:255) & $\mathbf{n}$ & $\%$ \\
\hline \multicolumn{3}{|l|}{ Gender } \\
\hline Female & 173 & 67.8 \\
\hline Male & 82 & 32.2 \\
\hline \multicolumn{3}{|l|}{ Accommodation } \\
\hline State dormitory (CDI) & 83 & 32.5 \\
\hline Private dormitory & 19 & 7.5 \\
\hline At home with friends & 23 & 9.0 \\
\hline At home with family & 130 & 51.0 \\
\hline \multicolumn{3}{|l|}{ Economic situation } \\
\hline Good & 32 & 12.5 \\
\hline Middle & 206 & 80.8 \\
\hline Bad & 17 & 6.7 \\
\hline \multicolumn{3}{|l|}{ The reason to choose the nursing department } \\
\hline His/her own wish & 61 & 23.9 \\
\hline Family / environmental pressure & 45 & 17.6 \\
\hline Job guarantee & 149 & 58.5 \\
\hline \multicolumn{3}{|c|}{ Finding nursing education sufficient in the school } \\
\hline Enough & 101 & 39.6 \\
\hline Not enough & 154 & 60.4 \\
\hline \multicolumn{3}{|c|}{ Insufficient fields/factors in nursing education at the school* } \\
\hline Inadequate clinical practice & 172 & 67.5 \\
\hline Insufficiency of theoretical education & 83 & 32.5 \\
\hline Poor quality of education & 79 & 31.0 \\
\hline Physical space insufficiency & 143 & 56.1 \\
\hline Insufficient academic staff & 63 & 24.7 \\
\hline Lack of student affairs office work & 113 & 44.3 \\
\hline Social activity shortage & 179 & 70.2 \\
\hline \multicolumn{3}{|l|}{ Education status about professional values } \\
\hline Yes & 129 & 50.6 \\
\hline \multirow[t]{2}{*}{ No } & 126 & 49.4 \\
\hline & $\mathrm{X} \pm \mathrm{SD}$ & \\
\hline Age & $22.05 \pm 1.70$ & \\
\hline CGPA (Cumulative Grade Point Average) & $2.76 \pm 0.40$ & \\
\hline
\end{tabular}

${ }^{*}$ Multiple options were marked.

When the descriptive characteristics of the students participating in the study were examined (Table 1), 67.8\% of the students were female (average age of $22.05 \pm 1.70$ ), and had a CGPA of $2.76 \pm 0.40$. Of the participants, $51 \%$ stayed at home with their family, and it was determined that they chose their profession (58.5\%) because of the job guarantee. It was determined that most of the students did not find nursing education sufficient in the school (60.4\%) and they received training on professional values (50.6\%) (Table 1). Most of the students stated that social activity insufficiency $(70.2 \%)$, clinical practice insufficiency $(67.5 \%)$, and physical area insufficiency $(56.1 \%)$ were problematic issues in nursing education at the school where they were educated. 
Table 2. Comparison of Nursing Education Stress Level Scores according to students' descriptive characteristics

\begin{tabular}{|c|c|c|c|c|c|}
\hline Descriptive characteristics & $\mathbf{n}$ & $\%$ & $\mathrm{X} \pm \mathrm{SD}$ & Test & $\mathbf{p}$ \\
\hline \multicolumn{6}{|l|}{ Gender } \\
\hline Female & 173 & 67.8 & $65.64 \pm 13.97$ & \multirow{2}{*}{$\mathrm{t}=4.909$} & \multirow{2}{*}{$\mathrm{p}=0.000^{*}$} \\
\hline Male & 82 & 32.2 & $55.26 \pm 19.00$ & & \\
\hline \multicolumn{6}{|l|}{ Accommodation } \\
\hline State dormitory (CDI) & 83 & 32.5 & $66.13 \pm 16.16$ & \multirow{4}{*}{$K W=9.032$} & \multirow{4}{*}{$\mathrm{p}=0.029^{\star}$} \\
\hline Private dormitory & 19 & 7.5 & $62.31 \pm 17.04$ & & \\
\hline At home with friends & 23 & 9.0 & $59.86 \pm 15.48$ & & \\
\hline At home with family & 130 & 51.0 & $60.29 \pm 16.47$ & & \\
\hline \multicolumn{6}{|l|}{ Economic situation } \\
\hline Good & 32 & 12.5 & $57.59 \pm 20.42$ & \multirow{3}{*}{$K W=2.783$} & \multirow{3}{*}{$p=0.249$} \\
\hline Middle & 206 & 80.8 & $62.62 \pm 15.89$ & & \\
\hline Bad & 17 & 6.7 & $67.35 \pm 13.61$ & & \\
\hline \multicolumn{6}{|c|}{ The reason to choose the nursing department } \\
\hline His/her own wish & 61 & 23.9 & $59.85 \pm 15.25$ & \multirow{3}{*}{$\mathrm{F}=0.893$} & \multirow{3}{*}{$p=0.411$} \\
\hline Family/env. pressure & 45 & 17.6 & $63.24 \pm 17.39$ & & \\
\hline Job guarantee & 149 & 58.5 & $63.02 \pm 16.66$ & & \\
\hline \multicolumn{6}{|c|}{ Finding nursing education sufficient in the school } \\
\hline Enough & 101 & 39.6 & $62.05 \pm 16.94$ & \multirow{2}{*}{$t=-0.193$} & \multirow{2}{*}{$p=0.847$} \\
\hline Not enough & 154 & 60.4 & $62.46 \pm 16.19$ & & \\
\hline \multicolumn{6}{|l|}{ Education status about professional values } \\
\hline Yes & 129 & 50.6 & $62.87 \pm 17.02$ & \multirow{2}{*}{$\mathrm{t}=0.559$} & \multirow{2}{*}{$p=0.577$} \\
\hline No & 126 & 49.4 & $61.72 \pm 15.91$ & & \\
\hline Age & & & $22.05 \pm 1.70$ & $r=0.021$ & $p=0.744$ \\
\hline CGPA (Cumulative Grade Point Average) & & & $2.76 \pm 0.40$ & $r=-0.006$ & $p=0.929$ \\
\hline
\end{tabular}

$p<0.05^{*}$

In Table 2, when the nursing education stress level scores averages were compared according to the students' descriptive characteristics, there was a significant difference in the nursing education stress level average scores $(p<0.05)$ with respect to gender and accommodation. There was no significant difference in nursing education stress level average scores with respect to the students' age, CGPA, economic status, reason for choosing the nursing department, finding the nursing education adequate, and/or education status regarding professional values $(p>0.05)$. 
Table 3. Comparison of the average scores of the students' perception of professional values based on their descriptive characteristics

\begin{tabular}{|c|c|c|c|c|c|}
\hline Descriptive Characteristics & $\mathbf{n}$ & $\%$ & $\mathrm{X} \pm \mathrm{SD}$ & Test & $\mathbf{p}$ \\
\hline \multicolumn{6}{|l|}{ Gender } \\
\hline Female & 173 & 67.8 & $95.01 \pm 17.92$ & \multirow{2}{*}{$t=2.336$} & \multirow{2}{*}{$\mathrm{p}=0.020^{\circ}$} \\
\hline Male & 82 & 32.2 & $89.64 \pm 15.38$ & & \\
\hline \multicolumn{6}{|l|}{ Accommodation } \\
\hline State dormitory (CDI) & 83 & 32.5 & $92.73 \pm 17.74$ & \multirow{4}{*}{$\mathrm{KW}=0.171$} & \multirow{4}{*}{$p=0.982$} \\
\hline Private dormitory & 19 & 7.5 & $93.26 \pm 16.33$ & & \\
\hline At home with friends & 23 & 9.0 & $94.52 \pm 13.04$ & & \\
\hline At home with family & 130 & 51.0 & $93.43 \pm 17.96$ & & \\
\hline \multicolumn{6}{|l|}{ Economic situation } \\
\hline Good & 32 & 12.5 & $91.46 \pm 15.77$ & \multirow{3}{*}{$K W=3.903$} & \multirow{3}{*}{$p=0.142$} \\
\hline Middle & 206 & 80.8 & $94.06 \pm 17.63$ & & \\
\hline Bad & 17 & 6.7 & $87.35 \pm 15.34$ & & \\
\hline \multicolumn{6}{|l|}{ The reason to choose the nursing department } \\
\hline His/her own wish & 61 & 23.9 & $95.21 \pm 15.48$ & \multirow{3}{*}{$F=0.552$} & \multirow{3}{*}{$p=0.577$} \\
\hline Family/env. pressure & 45 & 17.6 & $91.91 \pm 18.89$ & & \\
\hline Job guarantee & 149 & 58.5 & $92.91 \pm 17.55$ & & \\
\hline \multicolumn{6}{|c|}{ Finding nursing education sufficient in the school } \\
\hline Enough & 101 & 39.6 & $91.58 \pm 14.75$ & \multirow{2}{*}{$\mathrm{t}=-1.277$} & \multirow{2}{*}{$p=0.203$} \\
\hline Not enough & 154 & 60.4 & $94.40 \pm 18.74$ & & \\
\hline \multicolumn{6}{|l|}{ Education status about professional values } \\
\hline Yes & 129 & 50.6 & $94.98 \pm 16.92$ & \multirow{2}{*}{$t=1.587$} & \multirow{2}{*}{$p=0.114$} \\
\hline No & 126 & 49.4 & $91.55 \pm 17.57$ & & \\
\hline Age & & & $22.05 \pm 1.70$ & $r=0.090$ & $p=0.153$ \\
\hline CGPA (Cumulative Grade Point Average) & & & $2.76 \pm 0.40$ & $r=-0.002$ & $p=0.976$ \\
\hline
\end{tabular}

$p<0.05^{*}$

When the average scores of the perception of professional values according to the students' descriptive characteristics were compared (Table 3), there was a significant difference $(p<0.05)$ in the perception level of professional values based on gender. No significant difference in the perception level of professional values according to the students' age, CGPA, accommodation, economic status, reason for choosing the nursing department, the status of finding nursing education sufficient and their education status regarding professional values was determined $(p>0.05)$.

Table 4. Distribution of Nursing Education Stress Scale (NESS) and Nurses' Professional Values Scale (NPVS) item average points

\begin{tabular}{lcc} 
Scale and Factors & Min-Max & Average \pm SD \\
\hline NESS (Total Point) & $0-96$ & $62.30 \pm 16.46$ \\
Academic Stress & $0-48$ & $30.59 \pm 8.19$ \\
Clinical Stress & $0-48$ & $30.59 \pm 8.19$ \\
NPVS (Total Point) & $26-130$ & $93.29 \pm 17.30$ \\
Care & $15-75$ & $55.60 \pm 10.80$ \\
Professionalism & $8-40$ & $27.16 \pm 5.88$ \\
Confidence & $3-15$ & $10.52 \pm 2.28$ \\
\hline
\end{tabular}

NESS total score average of the students was determined as $62.30 \pm 16.46$. When the mean scores of the sub-dimensions were examined, Academic Stress was found to be $30.59 \pm 8.19$, and Clinical Stress was $30.59 \pm 8.19$ (Table 4). The total mean score of NPVS was $93.29 \pm 17.30$. The mean scores related to the factors were $55.60 \pm 10.80$ for Care, $27.16 \pm 5.88$ for Professionalism, and $10.52 \pm 2.28$ for Confidence (Table 4). 
Table 5. The relationship between nursing education stress scale and its sub-dimensions and nurses' professional values scale and its factors

\begin{tabular}{|c|c|c|c|c|c|}
\hline & & NPVS (Total Score) & Care & Professionalism & Confidence \\
\hline \multirow[t]{2}{*}{ NESS (Total Score) } & $r$ & 0.197 & 0.191 & 0.181 & 0.124 \\
\hline & $\mathbf{p}$ & $0.002^{\star}$ & $0.002^{*}$ & $0.004^{\star}$ & $0.049^{*}$ \\
\hline \multirow[t]{2}{*}{ Academic Stress } & $\mathbf{r}$ & 0.185 & 0.184 & 0.168 & 0.100 \\
\hline & p & $0.003^{*}$ & $0.003^{*}$ & $0.007^{\star}$ & 0.112 \\
\hline \multirow[t]{2}{*}{ Clinical Stress } & $\mathbf{r}$ & 0.192 & 0.183 & 0.178 & 0.135 \\
\hline & $p$ & $0.002^{*}$ & $0.003^{*}$ & $0.004^{*}$ & $0.031^{*}$ \\
\hline
\end{tabular}

Pearson Correlation Analysis

$\mathrm{p}<0.05^{*}$

It was determined that there was a significant positive correlation between the total and sub-dimensions mean scores of the Nursing Education Stress Scale and the Nurses' Professional Values Scale total and factors' mean scores $(p<0.05)$ (Table 5). It was observed that, as the student nursing education stress level increased, perception of professional values increased.

\section{Discussion}

The development of professional values in nursing education is stated as an important issue (Bang et al., 2011; Lacobucci et al., 2012). Specifically, nursing students gain professional nursing identity during school and also develop/learn professional values during this time (Acaroğlu, 2014).

When the findings of this study are evaluated, students who participated in the research (58.5\%) preferred the nursing department because of the job guarantee. In a study conducted in 2019 by Tosunöz et al., it was stated that the thought that students participating in the study would not be unemployed in nursing was the most effective factor in choosing a profession after their desire to help people. In a study conducted in 2019 by Pazarcıkcı and Dilmen, it is stated that among the most important factors affecting the choice of profession of nursing students is the idea that they will not be unemployed in nursing. The studies carried out show similarities with the results of this research (Pazarcıkcı \& Dilmen 2019; Tosunöz et al. 2019). It is thought that this similarity stems from the fact that the nursing profession is one of the most highly employable professions in Turkey today, and that the majority of students prefer this profession because of the job guarantee.

It was determined that nursing education stress level of female students participating in the study was higher than that of male students. In a study conducted in 2018 by Kılıç, it was determined that female students participating in the study had higher Nursing Education Stress Scale total score and academic stress sub-dimension mean scores. Also, in other done studies, the nursing education stress level of female students was found to be higher than male students, and is similar this situation research findings (Akkaya, Gümüş \& Akkuş, 2018; Ergin, Çevik \& Çetin, 2018; Kılıç, 2018). It is thought that this similarity stems it can be thought that female students are more anxious than male students because of their psychological structure.

In this study, the nursing education stress level of students staying in the State dormitory (Credit and Dormitories Institution) was statistically higher than those staying elsewhere. Similarly, in a study conducted by Büyükbayram and Ayık in 2020 , the Nursing Education Stress Scale and all sub-dimension mean scores of students living in dormitories were found to be higher than those living in other places. Since the living conditions (food, cleaning, physical environment, and study environment etc.) of the students staying at the dormitory are more difficult than the students staying at home, their stress level may be higher. Because the dormitory environment is crowded, the high noise level suggests that it is difficult to find a calm and suitable environment for studying. Therefore, stress levels may increase when students cannot study effectively.

This research is students' total NESS scores were determined as high. As the highest score obtained from the scale is 96, the educational stresses of the students were found above the average. When evaluating the mean scores related to the sub-dimensions, both Academic Stress score average and Clinical Stress score average were determined to be equally high. The results of this research are similar to the results of other studies conducted in Turkey (Ağaçdiken, Boğa \& Özdelikara, 2016; Akkaya, Gümüş \& Akkuş, 2018; Ergin, Çevik \& Çetin, 2018; Kılıç, 2018). Similarly, in a study conducted in 2018 by Akkaya et al., students' NESS total score average, clinical stress score average and academic stress score 


\section{Educational stress level of nursing students}

Hemşirelik öğrencilerinin eğitim stres düzeyi

average were found to be high. Difficulty in university education and difficulties in theoretical and clinical practice courses can increase the stress level of students.

In this study, the total score of NSPV was determined to be high. In this study, students' the total score of NSPV was determined to be high. Since the highest score obtained from the scale was 130, it was found that students' perception level of professional values was above average. The results of this research are similar to the results of other studies conducted (Arkan, Ordin \& Haney, 2019; Bang et al. 2011; Can \& Acaroğlu, 2015; Caner et al., 2019; Dündar et al., 2019; Lacobucci et al., 2012; Uslusoy et al., 2017). In a study conducted in 2020 by Elmalı, as a result of the evaluation of the Nurses' Professional Values Scale, which is used to determine the professional value perceptions of nursing students, the total score averages of the students were found to be high. Similarly, in a study conducted in 2019 by Arkan et al., the average of nursing students' nursing professional values was found to be good. In a study conducted in 2018 by Alkaya et al., the professional value scores of American and Turkish nursing students who participated in the study are found to be high. In a study conducted in 2012 by Lacobucci et al., it was determined that the professional values of senior nursing students were high. In the theoretical and practical courses from the first grade until the graduation, it is thought that the necessary professional consciousness has been created by the teachers in the field in order for the students to assimilate all the professional values. The formation of professional awareness can be said to affect the level of professional responsibility and increases the perception of professional values in students.

As a result of this research it was determined that there was a positive correlation between the total and sub-dimensions' scores of the Nursing Education Stress Scale and the Nurses' Professional Values Scale total score and its factors' scores. It has been observed that as students' nursing education stress level increases, their perception of professional values increases. In a study contucted, it was determined that as the stress experienced in the practice areas of nursing students increased, their professional satisfaction increased, and as their total stress and academic stress increased, their professional qualifications increased (Karabulutlu, Oruç \& Turan, 2019). Increase in students' nursing education stress level; it is thought that by providing the formation of professional awareness, it increases the sense of professional responsibility and increases the level of perception of professional values.

\section{Conclusion and Suggestions}

The following results were obtained in this research conducted to determine the relationship between the nursing education stress level and senior nursing students' perception level of professional values:

- Nursing education stress level of the senior year students was observed to be high.

- Senior nursing students' level of perception of professional values was found to be good.

- It has been found that there is a positive relationship between the nursing education stress level and senior nursing students' perception level of professional values.

In line with the results of this research, it is important determining the factors that cause stress in academic and clinical application areas and recognizing nursing education programs that will help nursing students to cope with these stress factors and reduce their stress is important.

Implications for Nursing Practice: This research is expected to be a precursor to interventional studies to reduce the stress levels of nursing students. Academicians in the field of nursing can take various trainings and apply them in classes to reduce the stress level of students. In addition, low educational stress will reduce students' mistakes in clinical practice. In this way, both patient safety will be preserved and will enable students to practice nursing with a high motivation and professional value perception. During the clinical practice training of students in administrative nurses, with schoolclinical cooperation should help reduce the factors that cause stress in students and be a good role model for vocational professionalism.

Ethics Committee: Approval was obtained from Inonu Univertiy, The Ethics Committee of Health Sciences NonInterventional Clinical Studies and the Ethics Committee on Scientific Research and Publication (Decision No: 2020/237). Conflict of Interest: Not reported.

Funding: None.

Informed Consent: Written informed consents of the participants were obtained. 


\section{Educational stress level of nursing students}

Hemşirelik öğrencilerinin eğitim stres düzeyi

\section{References}

Acaroğlu, R. (2014). Revize edilen hemşirelerin mesleki değerleri ölçeği Türkçe formunun güvenirlik ve geçerliği. Florence Nightingale Hemşirelik Dergisi, 22(1), 8-16.

Ağaçdiken, S., Boğa, N. \& Özdelikara, A. (2016). Hemşirelik öğrencilerinin hemşirelik eğitimine yönelik yaşadıkları stres düzeyinin belirlenmesi. Samsun Sağlık Bilimleri Dergisi, 1(1), 25-41.

Akkaya, G., Gümüş, A. \& Akkuş, Y. (2018). Hemşirelik öğrencilerinin eğitim stresini etkileyen faktörlerin belirlenmesi. Hemşirelikte Eğitim ve Araştırma Dergisi, 15(4), 202-208. https://doi.org/10.5222/HEAD.2018.202

Alkaya, S., Yaman, Ş. \& Simones, J. (2018). Professional values and career choice of nursing students. Nursing Ethics, 25(2), $243-252$. https://doi.org/10.1177/0969733017707007

Arkan, G., Ordin, Y. \& Haney, M. (2019). Hemşirelik öğrencilerinin mesleki değerleri ve tükenmişlik düzeyi arasındaki ilişki. Acıbadem Üniversitesi Sağlık Bilimleri Dergisi, 10(3), 443-450. https://doi.org/10.31067/0.2018.82

Arries, E. (2020). Professional values and ethical ideology: Perceptions of nursing students. Nursing Ethics, 27(3), 726-740. https://doi.org/10.1177/0969733019889396

Avcı, S., Işık, G., Cetişli, N., Üşümez, D., Şencandan, B. \& Bektaş, C. (2019). Hemşirelik öğrencilerinin profesyonel değerleri ve kariyer planları. Sağlık Bilimleri ve Meslekleri Dergisi, 6(2), 256-65. https://doi.org/10.17681/hsp.441835

Bang, K. S., Kang, J. H., Jun, M. H., Kim, H. S., Son, H. M., Yu, S. J., Kwon, M. K. \& Kim, J. S. (2011). Professional values in Korean undergraduate nursing students. Nurse Education Today, 31, 72-75. https://doi.org/10.1016/j.nedt.2010.03.019

Bleda, S., Alvarez, I. \& Prat, M. (2020). The perceptions of professional values among students at a Spanish nursing school. Healthcare, 8(74), 2-13. https://doi.org/10.3390/healthcare8020074

Blomberg, K., Bisholt, B., Engström, A. K., Johansson, A. S. \& Gustafsson, M. (2014). Swedish nursing students' experience of stress during clinical practice in relation to clinical setting characteristics and the organization of the clinical education. Journal of Clinical Nursing, 23, 2264-2271, https://doi.org/10.1111/jocn.12506

Büyükbayram, Z. \& Ayık, D. (2020). Hemşirelik öğrencilerinin hemşirelik eğitimi ile ilgili stres düzeylerinin belirlenmesi. Adnan Menderes Üniversitesi Sağlık Bilimleri Fakültesi Dergisi, 4(2), 90-99. https://doi.org/10.46237/amusbfd.562097.

Can, Ş. \& Acaroğlu, R. (2015). Hemşirelerin mesleki değerlerinin bireyselleştirilmiş bakım algıları ilişkisi. Florence Nightingale Hemşirelik Dergisi, 23(1), 32-40.

Caner, N., Efe, Y., Erdem, E., Başdaş, Ö., Bayat, M. \& Yıldırım, M. (2019). İntörn hemşirelerde mesleki değerler ve etik duyarılık. Sağlık Bilimleri Dergisi, 28(3), 123-128. doi.org/10.34108/eujhs.553135

Dündar, T., Özsoy, S., Toptaş. B. \& Aksu, H. (2019). Hemşirelikte mesleki değerler ve etkileyen faktörler. Ege Üniversitesi Hemşirelik Fakültesi Dergisi, 35(1), 11-19.

Elmalı, H. (2020). Hemşirelik öğrencilerinin profesyonel değer algılarının belirlenmesi. Hemşirelik Akademik Araştırma Dergisi (JAREN), 6(1), 125-131. https://doi.org/10.5222/jaren.2020.59272

Ergin, E., Çevik, K. \& Çetin, S. (2018). Hemşirelik öğrencilerinin eğitimlerine ilişkin algıladığı stres ve stresle baş etme davranışlarının incelenmesi. Hemşirelikte Eğitim ve Araştırma Dergisi, 15(1), 16-22. https://doi.org/10.5222/HEAD.2018.016

Gray-Toft, P. \& Anderson, J. (1981). The nursing stress scale: Development of an instrument. Journal of Behavioural Assessment, 3(1), 11-23.

Karaca, A., Yıldırım, N., Ankaralı, H., Açıkgöz, F. \& Akkuş, D. (2014). Hemşirelik eğitimi stres ölçeği'nin Türkçe'ye uyarlanması. Hemşirelikte Araştırma Geliştirme Dergisi, 16(2), 29-40. 


\section{Educational stress level of nursing students}

Hemşirelik öğrencilerinin eğitim stres düzeyi

Karadağlı, F. (2016). Hemşirelik öğrencilerinin profesyonel değer algıları ve etkileyen faktörler. Mersin Üniversitesi Sağlık Bilimleri Dergisi, 9(2), 81-91.

Karabulutlu, E., Oruç, F. \& Turan, G. (2019). Öğrencilerin hemşirelik eğitimi sürecinde yaşadıkları stresin profesyonel benlik gelişimlerine etkisi. Gümüşhane Üniversitesi Sağlık Bilimleri Dergisi, 8(1), 10-17.

Kılıç, H. (2018). Hemşirelik öğrencilerinin eğitim stresi ve mesleki benlik saygısı arasındaki ilişki. Hacettepe Üniversitesi Hemşirelik Fakültesi Dergisi, 5(1), 49-59.

Lacobucci, T., Daly, B., Lindell, D. \& Griffin, M. Q. (2012). Professional values, self-esteem, and ethical confidence of baccalaureate nursing students. Nursing Ethics, 20(4), 479-490.

Orak, N. Ş. \& Alpar, Ş. E. (2012). Validity and reliability of the nurses' professional values scale's Turkish version. Marmara Üniversitesi Sağıık Bilimleri Enstitüsü Dergisi, 2, 22-31.

Pazarcıkcı, F. \& Dilmen, B. (2019). Hemşirelik eğitimine yeni başlayan öğrencilerin meslek seçimini etkileyen faktörler ile boyun eğici davranışları arasındaki ilişkinin incelenmesi. Süleyman Demirel Üniversitesi Vizyoner Dergisi, 10(25), 599-611.

Reeve, K., Shumaker, C., Yearwood, E., Crowell, N. \& Riley, J. (2013). Perceived stress and social support in undergraduate nursing students' educational experiences. Nurse Education Today, 33, 419-424. https://doi.org/10.1016/j.nedt.2012.11.009

Rhead, M. (1995). Stress among student nurses: Is it practical or academic? Journal of Clinical Nursing, 4(6), 369-376.

Schank, M. J. \& Weis, D. (2000). Exploring commonality of professional values among nurse educators in the United States and England. Journal of Nursing Education, 39, 41-44.

Singh, C., Sharma, S. \& Sharma, R. K. (2011). Level of stress and coping strategies used by nursing interns. Nursing and Midwifery Research Journal, 7(4), 152-160.

Tosunöz, İ. K., Eskimez, Z. \& Öztunç, G. (2019). Hemşirelik öğrencilerinin meslek seçimlerini etkileyen faktörler. Kocaeli Üniversitesi Sağlık Bilimleri Dergisi, 5(2), 91-97. https://doi.org/10.30934/kusbed.532097

Uslusoy, E., Gürdoğan, E. \& Aydınlı, A. (2017). Professional values of Turkish nurses: A descriptive study. Nursing Ethics, $24(4)$, 493. https://doi.org/10.1177/0969733015611072.

Weis, D. \& Schank, M. J. (2009). Development and psychometric evaluation of the nurses professional values scale-revised. Journal of Nursing Measurement, 17, 221-231. https://doi.org/10.1891/1061-3749.17.3.221 